\title{
Safety and efficacy of twice daily administration of KPI-I2I I\% for ocular inflammation and pain following cataract surgery
}

This article was published in the following Dove Medical Press journal:

Clinical Ophthalmology

\author{
Terry Kim ${ }^{\prime}$ \\ Kenneth Sall ${ }^{2}$ \\ Edward J Holland ${ }^{3}$ \\ R Kim Brazzell ${ }^{4}$ \\ Susan Coultas ${ }^{4}$ \\ Preeya K Gupta' \\ 'Department of Ophthalmology, \\ Duke University Eye Center, Durham, \\ NC, USA; ${ }^{2}$ Sall Research Medical \\ Center, Inc, Artesia, CA, USA; \\ ${ }^{3}$ Department of Ophthalmology, \\ Cincinnati Eye Institute, University \\ of Cincinnati, Cincinnati, OH, USA; \\ ${ }^{4}$ Kala Pharmaceuticals, Inc, Waltham, \\ MA, USA
}

Correspondence: RK Brazzell Kala Pharmaceuticals, Inc, 100 Beaver Street, Suite 20I, Waltham, MA 02453, USA

Tel +l 78I 9965263

Fax + I 78I 6420399

Email kim.brazzell@kalarx.com
Purpose: KPI-121 is a nanoparticle suspension of loteprednol etabonate with improved ocular pharmacokinetics compared with marketed formulations. The efficacy and safety of KPI-121 1\% ophthalmic suspension (INVELTYS ${ }^{\text {TM}}$ ) dosed twice daily (BID) were evaluated in participants who had undergone cataract surgery.

Materials and methods: In two multicenter, randomized, double-masked, parallel-group, vehicle-controlled clinical trials, 386 participants with $\geq$ grade 2 anterior chamber cells ( $\geq 6$ cells) on the day following routine cataract surgery were treated with KPI-121 $1 \%$ and 325 participants were treated with placebo (vehicle); each group was dosed BID for 2 weeks. Primary efficacy endpoints were complete resolution of ocular inflammation by slit-lamp biomicroscopy and complete resolution of subject-rated ocular pain at Days 8 and 15 with no rescue medication before Day 15 . Safety assessments included adverse events (AEs), visual acuity, intraocular pressure measurements, and evaluation of ocular AEs by slit-lamp biomicroscopy and dilated ophthalmoscopy.

Results: Both trials achieved statistical significance favoring KPI-121 1\% BID for both primary efficacy endpoints. Combined data analysis showed that significantly more participants treated with KPI-121 vs vehicle achieved complete resolution of anterior chamber cells at Days 8 and $15(P \leq 0.0001)$ and complete clearing of ocular pain at Days 4,8 , and $15(P<0.0001)$. AEs were reported more frequently with vehicle than KPI-121.

Conclusion: KPI-121 1\% ophthalmic suspension was effective in resolving postoperative ocular inflammation and pain when dosed BID for 2 weeks in patients following cataract surgery. KPI-121 was found to be safe and well tolerated in both trials.

Keywords: loteprednol etabonate, nanoparticle, mucus penetrating particles, postoperative ocular inflammation, pain

\section{Introduction}

Intraocular inflammation is an anticipated sequela of intraocular surgery, such as cataract removal and intraocular lens implantation, and is manifested principally as conjunctival injection, corneal edema, ciliary flush, and aqueous cells and flare. In general, trauma to the internal structures of the eye is accompanied by the production of prostaglandins and other vasoactive moieties, an increase in blood flow to the affected area, and extravasation of protein and cellular blood elements. Untreated inflammation may lead to complications such as cystoid macular edema and corneal scarring. ${ }^{1,2}$ Thus, managing and treating postoperative inflammation is an important goal following cataract surgery.

Current postoperative medication regimens commonly include topical corticosteroids. ${ }^{3}$ Treatment with corticosteroids is employed to reduce pain and discomfort, and to 
facilitate recovery of the blood-aqueous barrier. When administered at the time of surgery and during the immediate postoperative period, corticosteroids can reverse the clinical manifestations of inflammation. ${ }^{4}$ In the US, topical corticosteroids are routinely prescribed with four times daily (QID) dosing for at least 2 weeks following cataract surgery.

KPI-121 1\% (INVELTYSTM) was developed by Kala Pharmaceuticals, Inc. (Waltham, MA, USA) and recently approved by the US Food and Drug Administration (FDA) for the treatment of postoperative inflammation and pain following ocular surgery. ${ }^{5}$ KPI-121 1\% contains loteprednol etabonate (LE) $1 \%$ formulated using a proprietary technology known as mucus penetrating particles (MPP). MPP utilizes nanoparticles of drug formulated to enhance penetration of loteprednol through the mucus layer of the tear film, resulting in increased penetration into ocular tissues.

LE was chosen because it is an ester corticosteroid and is rapidly absorbed into ocular issues. After exerting its effects, loteprednol is rapidly metabolized to inactive metabolites and has been reported to have fewer side effects than traditional glucocorticoids. ${ }^{6}$ Preclinical studies have shown that loteprednol formulated with MPP technology achieved higher ocular exposure than Lotemax ${ }^{\circledR}$ ophthalmic suspension 0.5\% (Bausch + Lomb, Rochester, NY, USA), with peak concentrations approximately three-fold higher in ocular tissues and aqueous humor. ${ }^{7}$ The profile of KPI-121 has the potential to deliver potent anti-inflammatory activity with less frequent dosing, while still retaining the safety profile of loteprednol.

The purpose of the current research was to investigate the efficacy and safety of a twice daily (BID) dosing regimen of KPI-121 1\% ophthalmic suspension compared to placebo (hereafter referred to as vehicle) in subjects who experienced inflammation following routine, uncomplicated cataract surgery. Herein, the results are presented for two randomized, double-masked, vehicle-controlled, parallel-group trials comparing the safety and efficacy of KPI-121 1\% to vehicle in the treatment of subjects with postsurgical inflammation and pain following cataract surgery.

\section{Materials and methods Patients}

These trials included two samples of patients who underwent routine, uncomplicated cataract surgery (eg, phacoemulsification with posterior chamber intraocular lens implantation, not combined with any other surgery), had $\geq$ grade 2 anterior chamber cells (ie, $\geq 6$ cells), and had potential postoperative Snellen distance visual acuity (VA) by pinhole method of at least 20/200 in the study eye. The first trial (hereafter referred to as Trial 1) was conducted at 24 sites (Table S1) within the US between May 2014 and December 2014 and the second trial (hereafter referred to as Trial 2) was conducted at 35 sites (Table S2) within the US between June 2016 and March 2017. Each trial was designed and monitored in accordance with the ethical principles of Good Clinical Practice and the Declaration of Helsinki, and Institutional Review Board approval was obtained by each trial site. Written informed consent was obtained from all subjects at the time of their enrollment and prior to any screening evaluations for the trial.

Individuals of either sex or any race/ethnicity who were $\geq 18$ years and were candidates for routine, uncomplicated cataract surgery were eligible for participation in the trials. Patients who required concurrent ocular or non-ocular therapy with any type of medication (eg, nonsteroidal antiinflammatory drugs, mast cell stabilizers, antihistamines, or decongestants) within 2 days prior to surgery and for the duration of the study were excluded from the trial as were patients with a history of glaucoma, intraocular pressure (IOP) $>21 \mathrm{mmHg}$ at the screening or randomization visit(s), or were being treated for glaucoma in either eye. Also excluded were patients who: 1) had penetrating intraocular surgery in the study eye within 3 months or within 2 weeks in the fellow eye; 2) had selective laser trabeculoplasty within 3 months prior to surgery or had corneal refractive surgery, glaucoma surgery, or corneal transplantation (full thickness, anterior, or posterior) within a year prior to enrollment or were unstable and/or required medication; 3) had active uveitis in either eye or a diagnosis of any type of infection, disease, and/or severe/serious condition that would interfere with study drug effectiveness or study compliance.

\section{Design and treatment}

Both studies were randomized, double-masked, parallelgroup trials. Randomization was stratified by trial site. In Trial 1, two concentrations and dosing regimens of KPI-121 vs vehicle were administered to one eye for 2 weeks. Subjects were randomized to one of four treatment arms in a 2:2:1:1 ratio: 1) KPI-121 0.25\% QID, 2) KPI-121 1\% BID, 3) vehicle A QID, 4) vehicle B BID. Following the completion of Trial 1, which demonstrated favorable safety and efficacy profiles for both KPI-121 treatment groups, Trial 2 was initiated to evaluate the safety and efficacy of KPI-121 1\% BID compared with vehicle BID administered to one eye for 2 weeks.

As illustrated in Figure 1, subjects in both trials completed up to seven clinic visits (including the surgery day) over 18-33 days of total planned trial duration. Screening occurred 


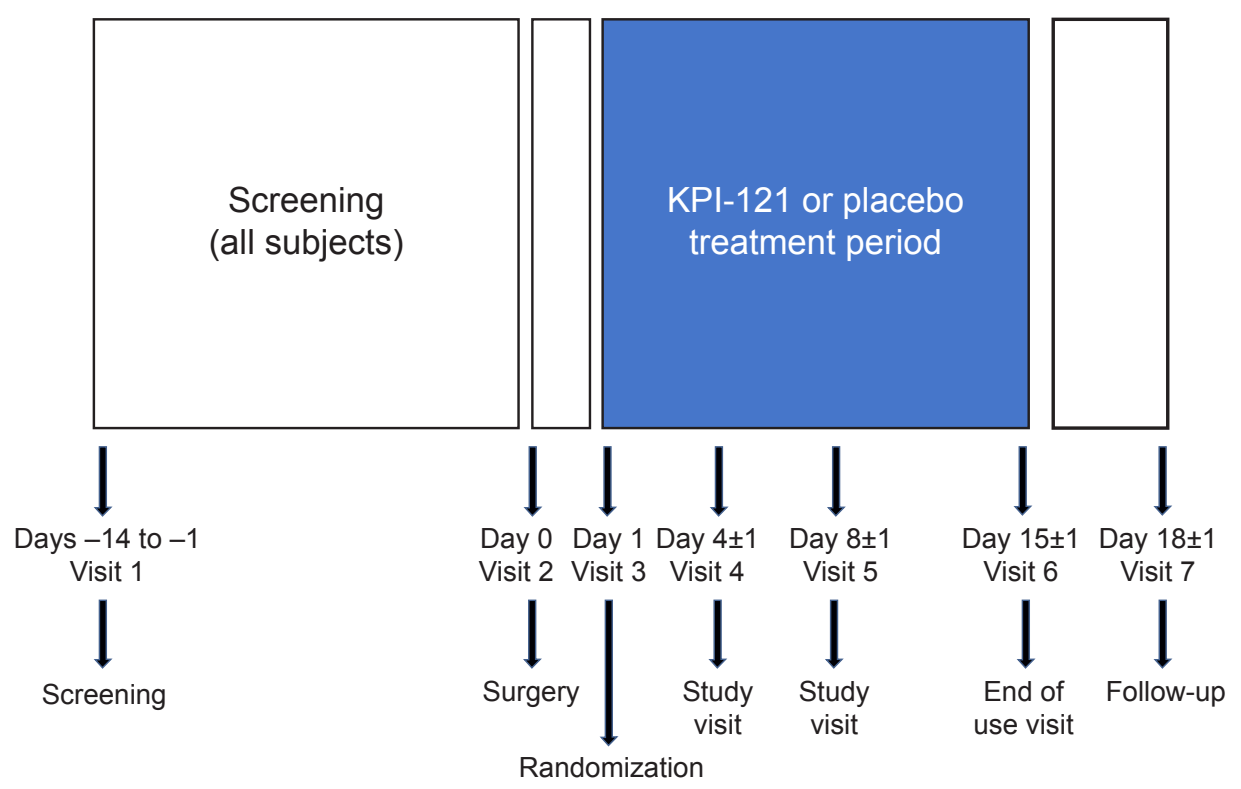

Figure I Schematic of the study design.

Notes: In both Trial I and Trial 2, subjects completed up to seven clinic visits (including the surgery day) over I8-33 days of total planned trial duration. Screening occurred prior to surgery, and subjects who met preoperative screening inclusion/exclusion criteria were enrolled in the trial. At Day 0 (surgery), subjects underwent routine, uncomplicated cataract surgery according to normal procedures. Randomization occurred on the day following surgery (Day I). Subjects self-administered I-2 drops in the study eye (defined as the surgery eye) for 14 days and returned to the clinic to be evaluated at Days 4,8 , and I5. The last dose of study treatment was administered on the morning of the Day 15 visit, upon completion of 14 days of dosing.

between 14 and 1 day(s) prior to surgery, and subjects who met the preoperative screening inclusion/exclusion criteria were allowed to participate in the trial. At Day 0 (surgery), subjects underwent routine, uncomplicated cataract surgery according to normal procedures. Randomization occurred on the day following surgery (Day 1). Subjects who met the qualifying postoperative randomization criteria were eligible for randomization and initiated dosing with study treatment on that day. Subjects self-administered 1-2 drops in the study eye (defined as the surgery eye) for 14 days and recorded dosing information in a daily diary. Following initiation of study treatment dosing, subjects returned to the clinic to be evaluated at Days 4, 8, and 15. The last dose of study treatment was administered on the morning of the Day 15 visit, upon completion of the 14 days of dosing. Following the Day 15 visit, subjects were asked to return to the clinic once between Days 17 and 19 for follow-up and, following completion of all study procedures, were exited from the trial. Efficacy measures were performed on Days 4, 8, and 15. Adverse events (AEs) were assessed across the entire study period.

\section{Primary efficacy endpoints}

\section{Anterior chamber cell grade (slit-lamp biomicroscopy)}

Ocular inflammation was evaluated by an anterior chamber cell assessment of the study eye performed by the investigator via slit-lamp biomicroscopy. Investigators rated the subjects' anterior chamber cell grade using a 5 -point scale $(0=$ no cells seen; $1=1-5$ cells; $2=6-15$ cells; $3=16-30$ cells; $4=>30$ cells $)$. Complete resolution of inflammation was defined as an anterior chamber cell grade $=0$.

\section{Subject-rated ocular pain assessment}

Ocular pain was rated by the subject-rated ocular pain assessment using a 6 -point scale $(0=$ none; $1=$ minimal; $2=$ mild; $3=$ moderate; $4=$ moderately severe; $5=$ severe). Complete resolution of ocular pain was defined as a grade $=0$.

\section{Safety evaluation}

Safety assessments included evaluation of AEs, Snellen distance VA by pinhole method, IOP measurement, slit-lamp biomicroscopy (palpebral conjunctival erythema, corneal edema, hyphema, ciliary flush, and bulbar conjunctival injection), dilated ophthalmoscopy, and use of rescue medication.

\section{AEs}

An AE was defined as any untoward medical occurrence in a clinical investigation subject administered a pharmaceutical product that does not necessarily have a causal relationship with this treatment. Treatment-emergent AEs were defined as those events with onset after the first dose of study treatment or, if occurring prior to the first dose, worsened 
after administration of the first dose. The severity of AEs was classified as mild, moderate, or severe. The relatedness of AEs to the investigational product was also evaluated. Serious AEs were defined as ones resulting in death or that were life threatening, represented a persistent or significant incapacity or substantial disruption of the ability to conduct normal life functions, resulted in inpatient hospitalization or prolongation of existing hospitalization, a congenital anomaly/birth defect, or the occurrence of a significant medical event.

\section{Snellen distance VA}

Snellen distance VA was assessed at all study visits except the surgery visit (Day 0). VA measurement was performed with the Snellen eye chart using the pinhole at a distance of 20 feet $(6 \mathrm{~m})$.

\section{IOP measurement}

IOP measurements were performed at all study visits except the surgery visit (Day 0) using Goldmann applanation tonometry according to the investigator's standard procedure.

\section{Slit-lamp biomicroscopy}

Slit-lamp biomicroscopy was also used as a safety measure to assess palpebral conjunctival erythema, corneal edema, hyphema, ciliary flush, and bulbar conjunctival injection at all study visits except the surgery visit (Day 0).

\section{Dilated ophthalmoscopy}

Dilated ophthalmoscopy assessment included evaluation of the optic nerve head for pallor and cupping (cup/disc ratio) and was performed at screening and on Day 15. For each subject, the investigator determined whether direct or indirect ophthalmoscopy should be used. Findings were recorded as normal or abnormal.

\section{Use of rescue medication}

At any time during the treatment period, any subject not responding adequately to the study treatment could be "rescued," or placed on alternate therapy, at the investigator's discretion. Any subject placed on rescue medication discontinued use of the study treatment and continued trial participation through the final visit (Day 17-19). Subjects who received rescue medication prior to Day 15 were considered treatment failures, but the need for rescue medication was not considered an AE. At some sites, anti-inflammatory medications were administered starting on Day 15 in the absence of anterior chamber cells as standard-of-care, and this was not considered as a rescue.

\section{Statistical analyses}

The primary population for all efficacy analyses was the intent-to-treat (ITT) population, which was defined as all randomized subjects with at least one post-baseline (baseline = Day 1 ) evaluation. The safety population was defined as all subjects who received at least one dose of the allocated study treatment and from whom at least one safety assessment was obtained after randomization. Imputation for missing data was not applied.

Data from the efficacy and safety evaluations conducted during Trials 1 and 2 were analyzed separately and pooled, given the similarity in study design and purpose. The two vehicle groups in Trial 1 were pooled for all analyses of Trial 1 findings, because preliminary analyses illustrated no statistically significant differences between the two vehicle groups for the primary efficacy endpoints (complete resolution of anterior chamber cells at Day 8 maintained through Day 15 without rescue medication prior to Day 15 $[P=0.3130]$; complete resolution of ocular pain at Day 8 maintained through Day 15 without rescue medication prior to Day $15[P=0.6320])$. Because the purpose of the present research was to evaluate KPI-121 1\% BID compared with vehicle, the results from the KPI-121 $0.25 \%$ QID group from Trial 1 are not summarized here. For pooled efficacy analyses, all vehicle groups (Trial 1 QID, Trial 1 BID, and Trial 2 BID) were pooled; for pooled safety analyses the Trial 1 and Trial 2 BID vehicle groups were pooled but the Trial 1 vehicle QID group was excluded from the analyses.

Primary efficacy endpoints in both trials were evaluated using hierarchical statistical testing using the chi-squared statistic, with the provision that testing would cease if any single hypothesis had a $P$-value $>0.05$. The primary endpoints were tested in the following sequence, comparing KPI-121 1\% vs vehicle: 1) the difference in the proportion of study eyes with complete resolution of anterior chamber cells (grade $=0$ ) at postoperative Day 8 maintained through Day $15 ; 2$ ) the difference in the proportion of study eyes with complete resolution of pain ( grade $=0$ ) at postoperative Day 8 maintained through Day 15. Key non-primary endpoints were defined as the difference in the proportions of study eyes with: 1) complete resolution of anterior chamber cells (grade $=0$ ) at postoperative Day $15 ; 2$ ) complete resolution of ocular pain (grade $=0$ ) at postoperative Day 4; and 3) complete resolution of ocular pain at postoperative Day 15. For each of these 
primary and key non-primary endpoints, subjects treated with rescue medication prior to Day 15 were considered as nonresponders.

Separate and pooled summaries were created for all safety measures: evaluation of AEs, VA, IOP, slit-lamp biomicroscopy, dilated ophthalmoscopy, and use of rescue medication.

\section{Results}

\section{Patient disposition and demographics}

Across the two trials, 900 subjects were enrolled and included in the ITT populations: 380 subjects in Trial 1 and 520 subjects in Trial 2. Of these 900 subjects, 386 subjects were treated with KPI-121 1\% BID, 125 subjects were treated with KPI-121 0.25\% QID, 325 subjects were treated with vehicle BID, and 60 subjects were treated with vehicle QID. As illustrated in Table 1, there were no significant differences in the demographics of the enrolled populations between the two trials, and there were no significant differences among the treatment groups within each trial. Mean (range) ages were 67.7 (38-89) years for the pooled KPI-121 1\% BID group ( $\mathrm{N}=386)$ and 69.4 (40-90) years for the pooled vehicle group $(\mathrm{N}=385)$. Both trials, considered individually as well as pooled, enrolled more females than males, with a majority of subjects being White and not Hispanic/Latino.

\section{Efficacy}

Statistically significant between-group differences were observed for both primary efficacy endpoints, in both Trials (Table 2).

Pooled analyses of the two trials also demonstrated statistically significant results favoring KPI-121 $1 \%$ over vehicle for each primary and key non-primary endpoint, as summarized in Table 3. Results for these endpoints are presented graphically in Figure 2 (for responders on anterior chamber cells at Days 8 and 15) and Figure 3 (for responders on ocular pain at Days 4, 8 , and 15).

In Trial 1, complete resolution of anterior chamber cells at Day 8 and maintained through Day 15 with no rescue medication prior to Day 15 was demonstrated in $31.2 \%$ of subjects in the KPI-121 1\% BID group, compared with 15.1\% of subjects in the pooled vehicle group (between-group difference for percent responders: 16.1, 95\% CI, 5.9-26.4, $P=0.0024)$. Complete resolution of ocular pain at Day 8 and maintained through Day 15 with no rescue medication prior to Day 15 was demonstrated in $53.6 \%$ of subjects in the KPI$1211 \%$ BID group, compared with $34.1 \%$ of subjects in the pooled vehicle group (between-group difference for percent responders: $19.5,95 \% \mathrm{CI}, 7.4-31.5, P=0.0019)$. Results for the key non-primary efficacy analysis were also significantly different favoring KPI-121 1\% over vehicle for each analysis.

Table I Demographics and baseline characteristics (ITT population)

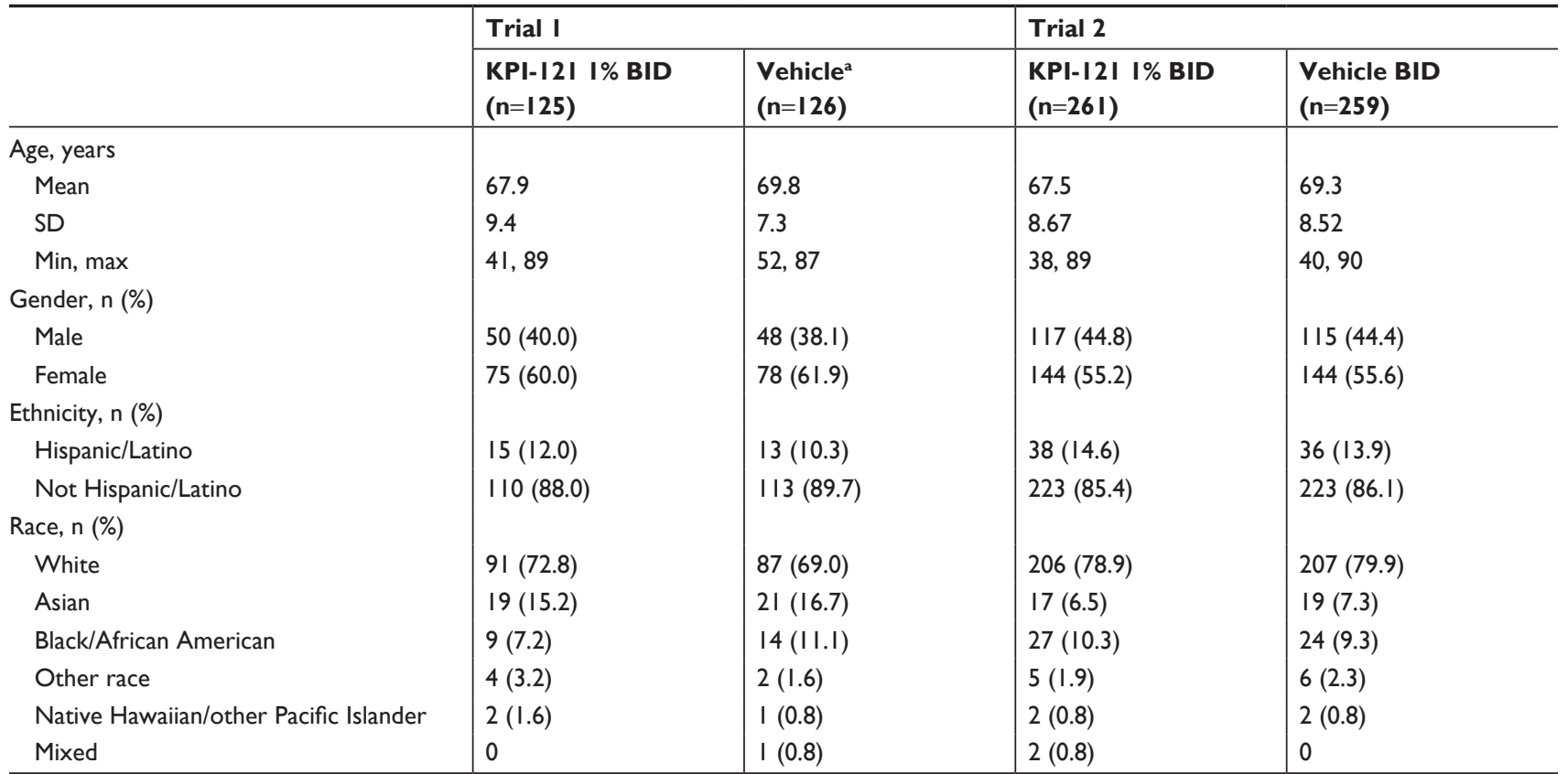

Notes: an Trial I, the two vehicle groups (vehicle A [QID] and vehicle B [BID]) were pooled for all analyses. For each trial, the ITT population was the primary population for all efficacy analyses.

Abbreviations: BID, twice daily; ITT, intent to treat; QID, four times daily. 
Table 2 Summary of efficacy results for KPI-I2I I\% BID and vehicle groups by trial (ITT populations)

\begin{tabular}{|c|c|c|c|c|c|c|}
\hline & \multicolumn{3}{|l|}{ Trial I } & \multicolumn{3}{|l|}{ Trial 2} \\
\hline & $\begin{array}{l}\text { KPI-I2I I\% BID } \\
(n=\mid 25)\end{array}$ & $\begin{array}{l}\text { Vehicle }^{a} \\
(n=126)\end{array}$ & $P$-value ${ }^{b}$ & $\begin{array}{l}\text { KPI-I2I I\% BID } \\
(n=26 I)\end{array}$ & $\begin{array}{l}\text { Vehicle BID } \\
(n=259)\end{array}$ & $P$-value ${ }^{b}$ \\
\hline $\begin{array}{l}\text { Primary endpoints, } \mathrm{n}(\%) \\
\text { Complete resolution of anterior chamber cells at } \\
\text { Day } 8 \text { maintained through Day } 15 \text { with no rescue } \\
\text { medication prior to Day } 15\end{array}$ & $39(31.2)$ & $19(15.1)$ & 0.0024 & $54(20.7)$ & $32(12.4)$ & 0.0105 \\
\hline $\begin{array}{l}\text { Complete resolution of ocular pain at Day } 8 \\
\text { maintained through Day } 15 \text { with no rescue } \\
\text { medication prior to Day } 15\end{array}$ & $67(53.6)$ & $43(34.1)$ & 0.0019 & I 49 (57.I) & $96(37.1)$ & $<0.0001$ \\
\hline $\begin{array}{l}\text { Key non-primary endpoints, } \mathrm{n}(\%) \\
\text { Complete resolution of pain at Day } 4 \text { maintained through }\end{array}$ & $55(44.0)$ & $32(25.4)$ & 0.0020 & $109(4 \mid .8)$ & $64(24.7)$ & $<0.0001$ \\
\hline $\begin{array}{l}\text { Day } 15 \text { with no rescue medication prior to Day } 15 \\
\text { Complete resolution of anterior chamber cells at } \\
\text { Day } 15 \text { with no rescue medication prior to Day } 15^{c}\end{array}$ & $68(54.4)$ & $38(30.2)$ & 0.0001 & $125(47.9)$ & $64(24.7)$ & $<0.0001$ \\
\hline $\begin{array}{l}\text { Complete resolution of pain at Day } 15 \text { with no } \\
\text { rescue medication prior to Day } 15^{c}\end{array}$ & 89 (7I.2) & $60(47.6)$ & 0.0001 & I 79 (68.6) & $126(48.6)$ & $<0.0001$ \\
\hline
\end{tabular}

Notes: aln Trial I, the two vehicle groups (vehicle A [QID] and vehicle B [BID]) were pooled for all analyses. ${ }^{\text {P }}$-values are based on two-sided chi-squared tests, unadjusted, wherein the significance level was 0.05 . 'Subjects with missing scores at Day 15 were counted as nonresponders for the Day 15 analyses. Complete resolution $=$ grade 0 , for all scales. A subject was not considered to have been rescued if rescue medication started on the Day 15 visit date.

Abbreviations: BID, twice daily; ITT, intent to treat; QID, four times daily.

In Trial 2, complete resolution of anterior chamber cells at Day 8 and maintained through Day 15 with no rescue medication prior to Day 15 was demonstrated in $20.7 \%$ of subjects in the KPI-121 1\% group, compared with $12.4 \%$ of subjects in the vehicle BID group (between-group difference for percent responders: $8.3,95 \% \mathrm{CI}, 2.0-14.7, P=0.0105$ ). Complete resolution of ocular pain at Day 8 and maintained through Day 15 with no rescue medication prior to Day 15 was demonstrated in $57.1 \%$ of subjects in the KPI- $1211 \%$ group, compared with $37.1 \%$ of subjects in the vehicle BID group (between-group difference for percent responders: 20.0, 95\% CI, 11.6-28.4, $P<0.0001)$. Results for the key non-primary efficacy analysis were also significantly different favoring KPI-121 1\% over vehicle BID for each analysis in both trials (Table 2).

\section{Safety \\ AEs}

In both Trial 1 and 2, considered individually and pooled, the incidence of AEs overall, treatment-related AEs, severe $\mathrm{AEs}$, and AEs leading to discontinuation of treatment was lower in the KPI-121 1\% BID group than the vehicle BID group (Tables 4 and 5). AEs were reported by 13.7\% (53/386) and $17.5 \%(57 / 325)$ of subjects in the KPI-121 1\% BID and

Table 3 Summary of efficacy results (pooled ITT populations)

\begin{tabular}{|c|c|c|c|}
\hline & $\begin{array}{l}\text { KPI-I2I I\% BID } \\
(n=386)\end{array}$ & $\begin{array}{l}V^{\text {Vehicle }}{ }^{\mathrm{a}} \\
(\mathrm{n}=385)\end{array}$ & $P$-value ${ }^{b}$ \\
\hline \multicolumn{4}{|l|}{ Primary endpoints, n (\%) } \\
\hline $\begin{array}{l}\text { Complete resolution of anterior chamber cells at Day } 8 \text { maintained through Day I5 } \\
\text { with no rescue medication prior to Day } 15\end{array}$ & $93(24.1)$ & $51(13.2)$ & 0.0001 \\
\hline $\begin{array}{l}\text { Complete resolution of ocular pain at Day } 8 \text { maintained through Day I } 5 \text { with no } \\
\text { rescue medication prior to Day I5 }\end{array}$ & $216(56.0)$ & $139(36.1)$ & $<0.0001$ \\
\hline \multicolumn{4}{|l|}{ Key non-primary endpoints, n (\%) } \\
\hline $\begin{array}{l}\text { Complete resolution of pain at Day } 4 \text { maintained through Day I } 5 \text { with no rescue } \\
\text { medication prior to Day I } 5\end{array}$ & $164(42.5)$ & $96(24.9)$ & $<0.0001$ \\
\hline $\begin{array}{l}\text { Complete resolution of anterior chamber cells at Day } 15 \text { with no rescue medication } \\
\text { prior to Day } 15^{c}\end{array}$ & $193(50.0)$ & $102(26.5)$ & $<0.0001$ \\
\hline Complete resolution of pain at Day 15 with no rescue medication prior to Day $15^{\mathrm{c}}$ & $268(69.4)$ & $186(48.3)$ & $<0.0001$ \\
\hline
\end{tabular}

Notes: aln Trial I, the two vehicle groups (vehicle A [QID] and vehicle B [BID]) were pooled for all analyses. This pooled vehicle group comprised both vehicle groups from Trial I and one vehicle group (dosed BID) in Trial 2. ${ }^{b}$-values are based on two-sided chi-squared tests, unadjusted, wherein the significance level was 0.05 . ${ }^{\mathrm{C}}$ Subjects with missing scores at Day 15 were counted as nonresponders for the Day 15 analyses. Complete resolution $=$ grade 0 , for all scales. A subject was not considered to have been rescued if rescue medication started on the Day I5 visit date.

Abbreviations: BID, twice daily; ITT, intent to treat; QID, four times daily. 
100

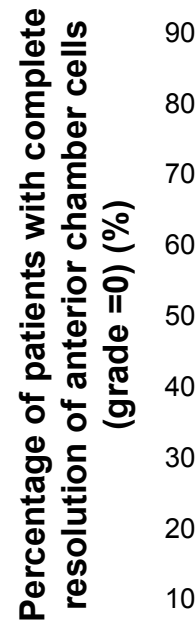

90

80

70

60

$P<0.0001$

$50 \%$

30

20

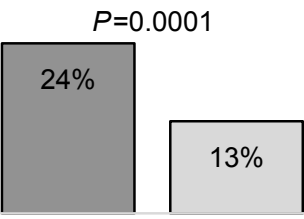

Day 8

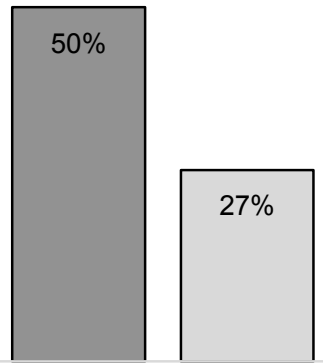

Day 15

$\square \mathrm{KPI}-121$ 1\% BID (N=386) $\square$ Vehicle $(\mathrm{N}=385)$

Figure 2 Proportions of subjects achieving and maintaining complete resolution of anterior chamber cells at Days 8 and I5 (pooled ITT population).

Notes: Data for the KPI-I2I I\% BID and vehicle treatment groups were pooled for both trials. Subjects were considered responders at Day X (ie, 8 or I5) if they had complete resolution of anterior chamber cells (grade $=0$ ) starting at that visit and continuing through Day 15 with no rescue medication prior to Day I5. A subject was not considered to have been rescued if rescue medication started on the Day 15 visit date. Subjects with missing scores at Day I 5 were counted as nonresponders for the Day I5 analysis. $P$-values are based on two-sided chi-squared tests, unadjusted, wherein the significance level was $P=0.05$.

Abbreviations: BID, twice daily; ITT, intent to treat.

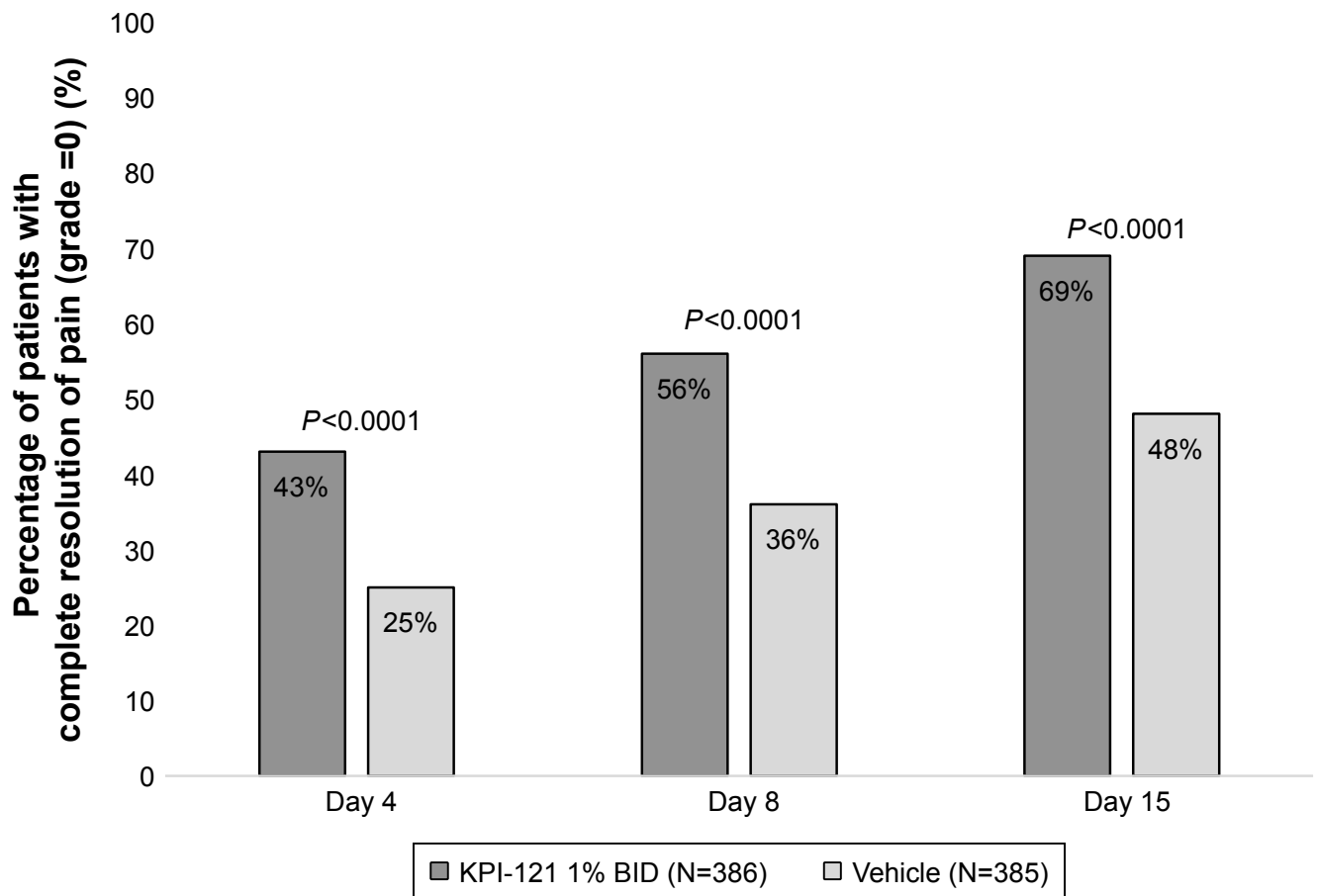

Figure 3 Proportions of subjects achieving and maintaining complete resolution of ocular pain at Days 4, 8, and I5 (pooled ITT population).

Notes: Data for the KPI-I2I I\% BID and vehicle treatment groups were pooled for both trials. Subjects were considered responders at Day X (ie, 4, 8, or I5) if they had complete resolution of ocular pain (grade $=0$ ) starting at that visit and continuing through Day 15 with no rescue medication prior to Day 15 . A subject was not considered to have been rescued if rescue medication started on the Day 15 visit date. Subjects with missing scores at Day I5 (five subjects in the KPI- 22 I $1 \%$ group and seven subjects in the vehicle group) were counted as nonresponders for the Day 15 analysis. $P$-values are based on two-sided chi-squared tests, unadjusted, wherein the significance level was $P=0.05$.

Abbreviations: BID, twice daily; ITT, intent to treat. 
Table 4 Number (\%) of subjects reporting AEs by category and trial (safety populations)

\begin{tabular}{|c|c|c|c|c|}
\hline & \multicolumn{2}{|l|}{ Trial I } & \multicolumn{2}{|l|}{ Trial 2} \\
\hline & $\begin{array}{l}\text { KPI-I2I I\% BID } \\
(n=\mid 25)\end{array}$ & $\begin{array}{l}\text { Vehicle }^{a} \\
(n=126)\end{array}$ & $\begin{array}{l}\text { KPI-I2I I\% BID } \\
(n=26 I)\end{array}$ & $\begin{array}{l}\text { Vehicle BID } \\
(n=259)\end{array}$ \\
\hline Any AEs & $15(12.0)$ & $26(20.6)$ & $38(14.6)$ & $42(16.2)$ \\
\hline AEs related to treatment ${ }^{\mathrm{b}}$ & I (0.8) & $9(7.1)$ & $9(3.4)$ & $7(2.7)$ \\
\hline Severe study eye $A E s^{c}$ & 0 & $3(2.4)$ & $2(0.8)$ & $2(0.8)$ \\
\hline Serious AEs & I (0.8) & $2(1.6)$ & I (0.4) & $2(0.8)$ \\
\hline AEs that led to discontinuation of treatment & $2(1.6)$ & $12(9.5)$ & $5(1.9)$ & $10(3.9)$ \\
\hline
\end{tabular}

Notes: an Trial I, the two vehicle groups (vehicle A [QID] and vehicle B [BID]) were pooled for all analyses. ${ }^{\mathrm{b}}$ Subjects reporting the same AE in more than one relationship category were counted in the greatest relationship category. 'Subjects reporting one or more AEs were counted once at the maximum intensity of all AEs.

Abbreviations: AE, adverse event; BID, twice daily; QID, four times daily.

vehicle BID groups, respectively. Most AEs were of mild or moderate severity. The most commonly reported $(\geq 1 \%$ in any treatment group) preferred terms were eye pain, headache, photophobia, posterior capsule opacification, corneal edema, and nasopharyngitis (Tables 6 and 7).

\section{VA}

In both Trial 1 and Trial 2, a review of Snellen distance VA data revealed no clinically important differences between the KPI-121 1\% BID group and the vehicle group in terms of mean changes from baseline in VA at any post-baseline assessment. Pooled summaries illustrated that changes from baseline in VA were negligible in both the KPI-121 1\% BID and vehicle groups.

\section{IOP}

In Trial 1 and Trial 2, as well as in the pooled analysis of both trials, mean IOP measurements of study eyes at each scheduled visit as well as increased IOP were similar across treatment groups (Table 8). Additionally, IOP elevations of $\geq 10 \mathrm{mmHg}$ compared with baseline and a raw IOP measurement of $\geq 21 \mathrm{mmHg}$ in the study eye were experienced by $0.5 \%(2 / 386)$ and $0 \%(0 / 325)$ of subjects in the KPI-121 $1 \% \mathrm{BID}$ and vehicle BID groups, respectively. Using a very strict definition of IOP elevation, $\geq 5 \mathrm{mmHg}$ increase and a raw IOP measurement of $\geq 21 \mathrm{mmHg}$ in the study eye, again both groups experienced similar incidence, $1.3 \%(5 / 386)$ and $0.6 \%(3 / 325)$ in the KPI-121 1\% BID and vehicle groups, respectively. These results indicate that no unexpected safety signal was observed relative to IOP following KPI-121 $1 \%$ treatment.

\section{Slit-lamp biomicroscopy}

In Trial 1 and Trial 2, as well as in the pooled analysis of both trials, no clinically important differences were observed based on safety evaluations of slit-lamp biomicroscopy (palpebral conjunctival erythema, corneal edema, hyphema, ciliary flush, and bulbar conjunctival injection) between the KPI-121 1\% BID and vehicle groups, and no significant differences from baseline were observed in either group.

\section{Dilated ophthalmoscopy}

In Trial 1 and Trial 2, as well as in the pooled analysis of both trials, no clinically important differences between the KPI-121 1\% BID and vehicle groups were observed based on evaluations from dilated ophthalmoscopy. There was a low prevalence of abnormal disc pallor and similar cup/disc ratio scores at both screening and Day 15 for KPI-121 $1 \%$ BID and vehicle groups.

Table 5 Number (\%) of subjects reporting AEs by category (pooled safety population)

\begin{tabular}{|c|c|c|}
\hline & $\begin{array}{l}\text { KPI-I2I I\% BID } \\
(n=386)\end{array}$ & $\begin{array}{l}\text { Vehicle BID } \\
(n=325)\end{array}$ \\
\hline Any AEs & $53(13.7)$ & 57 (I7.5) \\
\hline AEs in the study eye & $28(7.3)$ & $42(12.9)$ \\
\hline AEs related to treatment ${ }^{\mathrm{a}}$ & $10(2.6)$ & $12(3.7)$ \\
\hline Severe $A E s^{b}$ & $4(1.0)$ & $7(2.2)$ \\
\hline Serious AEs & $2(0.5)$ & $2(0.6)$ \\
\hline AEs that led to discontinuation of treatment & $7(1.8)$ & $17(5.2)$ \\
\hline
\end{tabular}

Notes: ${ }^{a}$ Subjects reporting the same AE in more than one relationship category were counted in the greatest relationship category. ${ }^{b}$ Subjects reporting one or more AEs were counted once at the maximum intensity of all AEs.

Abbreviations: AE, adverse event; BID, twice daily. 
Table 6 Number (\%) of subjects reporting common ( $\geq 1 \%$ in either group) AEs by trial (safety populations)

\begin{tabular}{|c|c|c|c|c|}
\hline & \multicolumn{2}{|l|}{ Trial I } & \multicolumn{2}{|l|}{ Trial 2} \\
\hline & $\begin{array}{l}\text { KPI-|2| I\% BID } \\
(n=\mid 25)\end{array}$ & $\begin{array}{l}V^{\text {Vehicle }}{ }^{a} \\
(n=126)\end{array}$ & $\begin{array}{l}\text { KPI- I2I I\% BID } \\
(n=26 I)\end{array}$ & $\begin{array}{l}\text { Vehicle BID } \\
(n=259)\end{array}$ \\
\hline Headache & $2(1.6)$ & $3(2.4)$ & $4(1.5)$ & $4(1.5)$ \\
\hline Corneal edema & $2(1.6)$ & $2(1.6)$ & 0 & 0 \\
\hline Eye pain & $\mathrm{I}(0.8)$ & $5(4.0)$ & $3(1.1)$ & $6(2.3)$ \\
\hline Photophobia & $\mathrm{I}(0.8)$ & $3(2.4)$ & $\mathrm{I}(0.4)$ & $4(1.5)$ \\
\hline Eye irritation & I (0.8) & $3(2.4)$ & 0 & 0 \\
\hline Nasopharyngitis & 0 & 0 & $4(1.5)$ & I (0.4) \\
\hline Posterior capsule opacification & 0 & 0 & $3(1.1)$ & $4(1.5)$ \\
\hline Cystoid macular edema & 0 & 0 & $3(1.1)$ & $3(1.2)$ \\
\hline Instillation site pain & 0 & 0 & $\mathrm{I}(0.4)$ & $2(1.2)$ \\
\hline Ocular hyperemia & 0 & $5(4.0)$ & 0 & 0 \\
\hline Eye inflammation & 0 & $4(3.2)$ & 0 & 0 \\
\hline Ocular discomfort & 0 & $2(1.6)$ & 0 & 0 \\
\hline
\end{tabular}

Notes: aln Trial I, the two vehicle groups (vehicle A [QID] and vehicle B [BID]) were pooled for all analyses. MedDRA version I6.I was used to code all AEs in each trial. Preferred terms are listed in descending order of incidence for the KPI-I2I I\% BID group in Trial I and then the KPI-I2I I\% BID group in Trial 2.

Abbreviations: AE, adverse event; BID, twice daily; QID, four times daily.

\section{Use of rescue medication}

Rescue medication was used at any time prior to Day 15 in Trial 1 by 14 patients (11.2\%) in the KPI-121 1\% group vs 48 patients $(38.1 \%)$ in the vehicle group, and in Trial 2 by 45 patients (17.2\%) in the KPI-121 1\% group vs 96 patients $(37.1 \%)$ in the vehicle group.

\section{Discussion}

Results from two double-masked, randomized, vehiclecontrolled trials provide evidence of the efficacy of KPI-121 $1 \%$ ophthalmic suspension administered twice daily for 2 weeks in the resolution of anterior chamber cells and ocular pain following cataract surgery. In both trials, a significantly greater proportion of subjects treated with KPI-121 1\% BID compared to vehicle demonstrated a response to treatment, in terms of complete resolution of anterior chamber cells (ie, grade $=0$ ) at Days 8 and 15 (each maintained through Day 15 without use of rescue medication) and complete clearing (ie, grade $=0$ ) of ocular pain at Days 4,8 , and 15 (each maintained

Table 7 Number (\%) of subjects reporting common ( $\geq 1 \%$ in either group) AEs (pooled safety population)

\begin{tabular}{l|l|l}
\hline & $\begin{array}{l}\text { KPI-I2 I I\% BID } \\
(\mathbf{n = 3 8 6})\end{array}$ & $\begin{array}{l}\text { Vehicle BID } \\
(\mathbf{n}=325)\end{array}$ \\
\hline Headache & $6(I .6)$ & $6(I .8)$ \\
Eye pain & $4(I .0)$ & $9(2.8)$ \\
Posterior capsule opacification & $4(1.0)$ & $4(1.2)$ \\
Nasopharyngitis & $4(1.0)$ & $1(0.3)$ \\
Photophobia & $2(0.5)$ & $6(1.8)$ \\
Corneal edema & $2(0.5)$ & $4(1.2)$ \\
\hline
\end{tabular}

Notes: MedDRA version 16.1 was used to code all AEs in each trial. Preferred terms are listed in descending order of incidence for the KPI- I2I I\% BID group. Abbreviations: $A E$, adverse event; $B I D$, twice daily. through Day 15 without use of rescue medication). Additionally, summaries of safety measures, including AEs, VA, IOP, slit-lamp biomicroscopy, dilated ophthalmoscopy, and use of rescue medication, demonstrated that KPI-121 1\% BID was also found to be safe and well tolerated with no new or unexpected safety concerns observed during the trial.

The AE profile was composed primarily of events that were local to the site of treatment, mild in severity, reversible, and nonserious, and most reported preferred terms were consistent with those that would be expected in a population that had recently undergone routine, uncomplicated cataract surgery and received topical ophthalmic corticosteroid treatment. AEs recognized as common with corticosteroid use were reported with low incidence in the KPI-121 1\% group. In the pooled analysis of AEs, the incidence of AEs was lower in the KPI-121 1\% group than in the vehicle group for all AEs overall, treatment-related AEs, severe AEs, and AEs leading to discontinuation of treatment.

As demonstrated in these two studies, KPI-121 1\% with MPP technology delivers a desirable combination of robust efficacy with twice daily dosing, a low overall incidence of AEs, and the favorable IOP-safety profile consistently demonstrated with LE. ${ }^{8-14}$ While the efficacy and safety of LE in treating postoperative inflammation and pain are well established, ${ }^{15-22}$ all currently available formulations require QID dosing. This is due at least in part to the eye's innate ability to remove foreign material, including suspended drug particles, from the ocular surface. One of the key mechanisms of this removal involves mucin, the primary component of mucus, which provides a key protective role for the ocular surface. The cornea and conjunctiva are covered with a 3- to 
Table 8 Summary of assessments of intraocular pressure in study eyes (pooled safety population)

\begin{tabular}{l|l|l}
\hline & $\begin{array}{l}\text { KPI- I 2I I\% BID } \\
(\mathbf{n = 3 8 6})\end{array}$ & $\begin{array}{l}\text { Vehicle BID } \\
(\mathbf{n}=\mathbf{3 2 5})\end{array}$ \\
\hline $\begin{array}{l}\text { Intraocular pressure (mmHg), } \mathrm{n}(\%) \\
>5 \mathrm{mmHg} \text { increase from baseline }\end{array}$ & $19(4.9)$ & $8(2.5)^{\mathrm{a}}$ \\
$>5 \mathrm{mmHg}$ increase from baseline $+21 \mathrm{mmHg}$ measurement & $5(1.3)$ & $3(0.6)^{\mathrm{a}}$ \\
$\geq 10 \mathrm{mmHg}$ increase from baseline & $3(0.8)$ & $0^{\mathrm{a}}$ \\
$\geq 10 \mathrm{mmHg}$ increase from baseline $+\geq 21 \mathrm{mmHg}$ measurement & $2(0.5)$ & $0^{\mathrm{a}}$ \\
\hline
\end{tabular}

Notes: ${ }^{a} n=320$; five subjects in the pooled vehicle group did not have any post-baseline IOP measurement.

Abbreviation: BID, twice daily.

$40-\mu \mathrm{m}$ layer of mucus. ${ }^{7,23-25}$ The outer layer of secreted and other mucins primarily traps and rapidly eliminates allergens, pathogens, and other particles (eg, corticosteroids in eye drops) while the cell-bound mucins of the inner glycocalyx protect the cornea from abrasive stress and turn over much less rapidly. ${ }^{7,26}$ The ability to penetrate the outer mucin matrix and reach the glycocalyx will likely increase the penetration and retention of drug particles on the ocular surface and enhance drug release to the underlying tissues. ${ }^{7}$ In order to penetrate the mucin meshwork effectively, particles must be sufficiently small in size $(<500 \mathrm{~nm})$ and have the ability to overcome the adhesive nature of the ocular mucus layer. ${ }^{27,28}$

MPP technology uses proprietary methods to create a novel nanoparticle formulation of LE designed to evade these mucus barriers. Coarse drug particles are milled in the presence of an MPP enabling surface-altering agent until the particle size is reduced to $\sim 200-400 \mathrm{~nm}$. In an ocular pharmacokinetic study in rabbits, a $0.4 \%$ suspension of LE-MPP produced peak concentrations approximately three-fold higher in ocular tissues (cornea, conjunctiva, iris/ciliary body, retina) and aqueous humor compared to Lotemax $^{\circledR}$ suspension. $^{7}$

KPI-121 $1 \%$ is a novel suspension of MPP-coated LE nanoparticles formulated with excipients approved by FDA for ophthalmic use. ${ }^{7}$ LE was selected for the formulation based upon several criteria including high lipophilicity, high binding affinity for the glucocorticoid receptor, and extensive and predictable metabolism to inactive metabolites by tissue esterases. $^{29}$

\section{Conclusion}

KPI-121 1\% given BID was effective in resolving postoperative inflammation and pain following cataract surgery, based on analyses demonstrating statistical significance compared with vehicle on the primary and key non-primary efficacy endpoints of pain and inflammation. It was safe and well tolerated with no new or unexpected safety concerns observed during the trials. KPI-121 1\% offers clinicians an efficacious
BID treatment option for inflammation and pain after ocular surgery which provides significant benefit to patients while retaining the favorable safety profile of loteprednol.

\section{Disclosure}

This study was sponsored and funded by Kala Pharmaceuticals, Inc, which participated in the design of the study and oversaw its conduct, monitoring, and analysis. Dr Kim, Dr Sall, Dr Holland, and Dr Gupta are consultants for Kala Pharmaceuticals, Inc. Dr Brazzell and Dr Coultas are employees of Kala Pharmaceuticals, Inc. The abstract of this paper was presented at the 2018 American Society of Cataract and Refractive Surgery (ASCRS) Annual Meeting as a paper presentation with interim findings. The paper's abstract was published in the "Paper Session Abstracts" on the ASCRS conference website: https://ascrs.confex.com/ascrs/18am/ meetingapp.cgi/Paper/47263.

\section{References}

1. American Academy of Ophthalmology. Cataract in the adult eye: preferred practice patterns; 2016. Available from: https://www.aao.org/ preferred-practice-pattern/cataract-in-adult-eye-ppp-2016. Accessed May 28, 2018.

2. El-Harazi SM, Feldman RM. Control of intra-ocular inflammation associated with cataract surgery. Curr Opin Ophthalmol. 2001;12(1):4-8.

3. Shoss BL, Tsai LM. Postoperative care in cataract surgery. Curr Opin Ophthalmol. 2013;24(1):66-73.

4. Leopold IH. Update on antibiotics in ocular infections. Am JOphthalmol. 1985;100(1):134-140.

5. INVELTYSTM (loteprednol etabonate ophthalmic suspension $1 \%$ ) [package insert]. Waltham, MA: Kala Pharmaceuticals Inc; 2018.

6. Druzgala P, Hochhaus G, Bodor N. Soft drugs-10. Blanching activity and receptor binding affinity of a new type of glucocorticoid: loteprednol etabonate. J Steroid Biochem Mol Biol. 1991;38(2):149-154.

7. Schopf L, Enlow E, Popov A, Bourassa J, Chen H. Ocular pharmacokinetics of a novel loteprednol etabonate $0.4 \%$ ophthalmic formulation. Ophthalmol Ther. 2014;3(1-2):63-72.

8. Howes JF, Baru H, Vered M, Neumann RON. Loteprednol etabonate: comparison with other steroids in two models of intraocular inflammation. J Ocul Pharmacol Ther. 1994;10(1):289-293.

9. Bartlett JD, Horwitz B, Laibovitz R, Howes JF. Intraocular pressure response to loteprednol etabonate in known steroid responders. J Ocul Pharmacol Ther. 1993;9(2):157-165.

10. Holland EJ, Djalilian AR, Sanderson JP. Attenuation of ocular hypertension with the use of topical loteprednol etabonate $0.5 \%$ in steroid responders after corneal transplantation. Cornea. 2009;28(10):1139-1143. 
11. Ilyas H, Slonim CB, Braswell GR, Favetta JR, Schulman M. Long-term safety of loteprednol etabonate $0.2 \%$ in the treatment of seasonal and perennial allergic conjunctivitis. Eye Contact Lens. 2004;30(1):10-13.

12. Rajpal RK, Digby D, D’Aversa G, Mah F, Hollander DA, Conway T. Intraocular pressure elevations with loteprednol etabonate: a retrospective chart review. J Ocul Pharmacol Ther. 2011;27(3):305-308.

13. Sheppard JD, Scoper SV, Samudre S. Topical loteprednol pretreatment reduces cyclosporine stinging in chronic dry eye disease. J Ocul Pharmacol Ther. 2011;27(1):23-27.

14. Sheppard JD, Comstock TL, Cavet ME. Impact of the topical ophthalmic corticosteroid loteprednol etabonate on intraocular pressure. Adv Ther. 2016;33(4):532-552.

15. Comstock TL, Paterno MR, Singh A, Erb T, Davis E. Safety and efficacy of loteprednol etabonate ophthalmic ointment $0.5 \%$ for the treatment of inflammation and pain following cataract surgery. Clin Ophthalmol. 2011;5:177-186.

16. Fong R, Leitritz M, Siou-Mermet R, Erb T. Loteprednol etabonate gel $0.5 \%$ for postoperative pain and inflammation after cataract surgery: results of a multicenter trial. Clin Ophthalmol. 2012;6:1113-1124.

17. Holzer MP, Solomon KD, Sandoval HP, Vroman DT. Comparison of ketorolac tromethamine $0.5 \%$ and loteprednol etabonate $0.5 \%$ for inflammation after phacoemulsification: prospective randomized double-masked study. J Cataract Refract Surg. 2002;28(1):93-99.

18. Lane SS, Holland EJ. Loteprednol etabonate $0.5 \%$ versus prednisolone acetate $1.0 \%$ for the treatment of inflammation after cataract surgery. J Cataract Refract Surg. 2013;39(2):168-173.

19. Loteprednol Etabonate Postoperative Inflammation Study Group. A double-masked, placebo-controlled evaluation of $0.5 \%$ loteprednol etabonate in the treatment of postoperative inflammation. Ophthalmology. 1998;105(9):1780-1786
20. Rajpal RK, Fong R, Comstock TL. Loteprednol etabonate ophthalmic gel $0.5 \%$ following cataract surgery: integrated analysis of two clinical studies. Adv Ther. 2013;30(10):907-923.

21. Stewart R, Horwitz B, Howes J, Novack GD, Hart K. Double-masked, placebo-controlled evaluation of loteprednol etabonate 0.5 for postoperative inflammation. J Cataract Refract Surg. 1998;24(11): 1480-1489.

22. Comstock TL, Sheppard JD. Loteprednol etabonate for inflammatory conditions of the anterior segment of the eye: twenty years of clinical experience with a retrometabolically designed corticosteroid. Expert Opin Pharmacother. 2018;19(4):337-353.

23. King-Smith PE, Fink BA, Fogt N, Nichols KK, Hill RM, Wilson GS. The thickness of the human precorneal tear film: evidence from reflection spectra. Invest Ophthalmol Vis Sci. 2000;41(11):3348-3359.

24. Prydal JI, Campbell FW. Study of precorneal tear film thickness and structure by interferometry and confocal microscopy. Invest Ophthalmol Vis Sci. 1992;33(6):1996-2005.

25. Prydal JI, Artal P, Woon H, Campbell FW. Study of precorneal tear film thickness and structure using laser interferometry. Invest Ophthalmol Vis Sci. 1992;33(6):2006-2011.

26. Mantelli F, Argüeso P. Functions of ocular surface mucins in health and disease. Curr Opin Allergy Clin Immunol. 2008;8(5):477-483.

27. Olmsted SS, Padgett JL, Yudin AI, Whaley KJ, Moench TR, Cone RA. Diffusion of macromolecules and virus-like particles in human cervical mucus. Biophys J. 2001;81(4):1930-1937.

28. Sigurdsson HH, Kirch J, Lehr C-M. Mucus as a barrier to lipophilic drugs. Int J Pharm. 2013;453(1):56-64.

29. Samir A, Bodor N, Imai T. Identification of esterase involved in the metabolism of two corticosteroid soft drugs. Biochem Pharmacol. 2017; $127: 82-89$. 


\section{Supplementary materials}

Table SI List and description of investigators, who enrolled at least one subject in the study, and other important participants in KPI-I2I I\% Trial I

\begin{tabular}{|c|c|c|}
\hline Investigator name & Sub-investigator(s) name & Hospital/institution name and address \\
\hline Ranjan P Malhotra, MD, FACS & $\begin{array}{l}\text { Gregg J Berdy, MD, FACS } \\
\text { Robert C Brusatti, OD }\end{array}$ & $\begin{array}{l}\text { Ophthalmology Associates, } \\
\text { I } 2990 \text { Manchester Road, Suite 200, } \\
\text { St Louis, MO 63I3I, USA }\end{array}$ \\
\hline Robert DaVanzo, MD & $\begin{array}{l}\text { Michael Emile Tepedino, MD } \\
\text { James Zachary Forsey, MD }\end{array}$ & $\begin{array}{l}\text { Cornerstone Eye Care, } \\
\text { I } 400 \text { East Hartley Drive, } \\
\text { High Point, NC 27262, USA }\end{array}$ \\
\hline Alice Epitropoulos, MD & & $\begin{array}{l}\text { Ophthalmic Surgeons \& Consultants of Ohio, } \\
262 \text { Neil Avenue, Suite 430, } \\
\text { Columbus, OH 43215, USA }\end{array}$ \\
\hline Raymond Fong, MD & $\begin{array}{l}\text { Jeffrey C Paccione, MD } \\
\text { Douglas B Friedrich, MD } \\
\text { Jason J Chen, OD }\end{array}$ & $\begin{array}{l}\text { Raymond Fong, MDPC, } \\
\text { I09 Lafayette Street, 4th floor, } \\
\text { New York, NY 10013, USA }\end{array}$ \\
\hline Joseph Gira, MD & $\begin{array}{l}\text { Micheal Donahoe, MD } \\
\text { Erin Sullivan, OD } \\
\text { Michelle Derhelmer, MD }\end{array}$ & $\begin{array}{l}\text { Ophthalmology Consultants Ltd, } \\
\text { I } 2990 \text { Manchester Road, Suite 20I, } \\
\text { St Louis, MO 63I3I, USA }\end{array}$ \\
\hline Damien Goldberg, MD & Barry Wolstan, MD & $\begin{array}{l}\text { Wolstan \& Goldberg Eye Associates, } \\
23600 \text { Telo Avenue, Suite 100, } \\
\text { Torrance, CA 90505, USA }\end{array}$ \\
\hline Paul J Hartman, MD & $\begin{array}{l}\text { Alan H Gruber, MD } \\
\text { Howard I Schenker, MD }\end{array}$ & $\begin{array}{l}\text { Rochester Ophthalmological Group, PC, } \\
\text { 2100 South Clinton Avenue, } \\
\text { Rochester, NY } 14618, \text { USA }\end{array}$ \\
\hline Farrell Tyson, MD & $\begin{array}{l}\text { Michael Tibbitts, MD } \\
\text { Stewart Kaplan, OD }\end{array}$ & $\begin{array}{l}\text { Argus Research at Cape Coral Eye Center, } \\
\text { 4I } 20 \text { Del Prado Boulevard S, } \\
\text { Cape Coral, FL 33904, USA }\end{array}$ \\
\hline Douglas Lorenz, DO & $\begin{array}{l}\text { Mark Stradling, DO } \\
\text { Surjeet Singh, MD } \\
\text { Rene Zamora, MD } \\
\text { Darrick Neibaur, DO } \\
\text { Vincent Gassen, OD } \\
\text { Douglas Orton, OD } \\
\text { Rajy Rouweyha, MD }\end{array}$ & $\begin{array}{l}\text { Nevada Eye and Ear, } \\
2598 \text { Windmill Parkway, } \\
\text { Henderson, NV 89074, USA } \\
\text { Las Vegas Physicians Research Group, } \\
870 \text { Seven Hills Drive, Suite 20I, } \\
\text { Henderson, NV 89052, USA } \\
\text { Seven Hills Surgical Center, } \\
876 \text { Seven Hills Drive, } \\
\text { Henderson, NV 89052, USA } \\
\text { Stone Creek Surgical Center, } \\
5915 \text { S Rainbow Boulevard, } \\
\text { Las Vegas, NV 89I I8, USA }\end{array}$ \\
\hline Joseph Martel, MD & James Martel, MD & $\begin{array}{l}\text { Martel Eye Medical Group, } \\
\text { I I } 216 \text { Trinity River Drive, } \\
\text { Rancho Cordova, CA 95670, USA } \\
\text { Martel Eye Institute, LLC, } \\
\text { I } 1216 \text { Trinity River Drive, } \\
\text { Rancho Cordova, CA 95670, USA } \\
\text { Mercy San Juan Surgery Center, } \\
6660 \text { Coyle Avenue, } \\
\text { Carmichael, CA 95608, USA }\end{array}$ \\
\hline
\end{tabular}


Table SI (Continued)

\begin{tabular}{|c|c|c|}
\hline Investigator name & Sub-investigator(s) name & Hospital/institution name and address \\
\hline Bernard Milstein, MD & Da-Thuy Van, DO & $\begin{array}{l}\text { The Eye Clinic of Texas, } \\
\text { Affiliate of Houston Eye Associates, } \\
\text { I } 100 \text { Gulf Freeway, Suite I I4, } \\
\text { League City, TX 77573, USA } \\
\text { Area Surgicare Center, } \\
502 \text { Medical Center Boulevard, } \\
\text { Webster, TX 77598, USA }\end{array}$ \\
\hline Sebastian Mora, MD & $\begin{array}{l}\text { John Kozlovsky, MD } \\
\text { Jeannie Camacho, OD }\end{array}$ & $\begin{array}{l}\text { Kozlovsky Delay \& Winter Eye Consultants, LLC, } \\
2929 \text { Mossrock, Suite 104, } \\
\text { San Antonio, TX 78230, USA }\end{array}$ \\
\hline Michael Nordland, MD, PhD & & $\begin{array}{l}\text { Cincinnati Eye Institute, } \\
\text { I } 945 \text { CEI Drive, } \\
\text { Cincinnati, OH 45242, USA } \\
\text { Cincinnati Eye Institute, } \\
470 \text { I Central Avenue, } \\
\text { Middletown, OH 45044, USA }\end{array}$ \\
\hline Francis Price, MD & $\begin{array}{l}\text { Yuri McKee, MD } \\
\text { Mathew Feng, MD } \\
\text { Kathleen Kelley, OD } \\
\text { Faye Peters, OD }\end{array}$ & $\begin{array}{l}\text { Price Vision Group, } \\
9002 \text { North Meridian Street, Suite 100, } \\
\text { Indianapolis, IN 46260, USA }\end{array}$ \\
\hline Charles Reilly, MD & $\begin{array}{l}\text { William Flynn, MD } \\
\text { Edward Rashid, MD } \\
\text { Robert Rice, MD }\end{array}$ & $\begin{array}{l}\text { R and R Eye Research, LLC, } \\
5430 \text { Fredericksburg Road, Suite 100, } \\
\text { San Antonio, TX 78229, USA } \\
\text { Specialty Surgery Center, } \\
5255 \text { Prue Road, Suite I00, } \\
\text { San Antonio, TX 78240, USA }\end{array}$ \\
\hline Lawrence Roel, MD & Richard M Francis, MD & $\begin{array}{l}\text { Westside Research, LLC, } \\
\text { I4I3 John B White Sr Boulevard, } \\
\text { Spartanburg, SC 29306, USA }\end{array}$ \\
\hline Kenneth Sall, MD & & $\begin{array}{l}\text { Sall Research Medical Center, } \\
\text { I I } 423 \text { 187th Street, Suite 200, } \\
\text { Artesia, CA 90701, USA }\end{array}$ \\
\hline John Sheppard, MD & $\begin{array}{l}\text { Walter O Whitley, OD } \\
\text { Elizabeth Yeu Lin, MD } \\
\text { Dayna Lago, MD } \\
\text { Stephen Scoper, MD }\end{array}$ & $\begin{array}{l}\text { Virginia Eye Consultants, } \\
24 \text { I Corporate Boulevard, } \\
\text { Norfolk, VA 23502, USA }\end{array}$ \\
\hline Robert J Smyth-Medina, MD & Steven Rauchman, MD & $\begin{array}{l}\text { North Valley Eye, II } 550 \text { Indian Hills Road, Suite 34I, } \\
\text { Mission Hills, CA 91345, USA }\end{array}$ \\
\hline Joseph Tauber, MD & No sub-investigator & $\begin{array}{l}\text { Tauber Eye Center, } \\
4400 \text { Broadway, Suite 202, } \\
\text { Kansas City, MO 64 I II, USA }\end{array}$ \\
\hline Lloyd Taustine, MD & $\begin{array}{l}\text { Gregory M Sulkowski, MD } \\
\text { Brian K Kritchman, MD } \\
\text { James D Hurt, OD }\end{array}$ & $\begin{array}{l}\text { Taustine Eye Center, I I } 69 \text { Eastern Parkway, } \\
\text { Suite } 3427 \text {, } \\
\text { Louisville, KY } 40217 \text {, USA }\end{array}$ \\
\hline Navin Tekwani, MD & & $\begin{array}{l}\text { Tekwani Vision Center, 991I Kennerly Road, Suite A, } \\
\text { St Louis, MO 63।28, USA }\end{array}$ \\
\hline Steve Wilson, OD & Timothy Schmitt, MD & $\begin{array}{l}\text { John-Kenyon, } 519 \text { State Street, } \\
\text { New Albany, IN 47I50, USA }\end{array}$ \\
\hline Harvey DuBiner, MD & $\begin{array}{l}\text { Ronald Weber, MD } \\
\text { Joon Y Kim, MD } \\
\text { Carey Jenkins, MD } \\
\text { Heather Ambrosia, MD } \\
\text { Kimberley Betton, OD }\end{array}$ & $\begin{array}{l}\text { Eye Care Centers Management, Inc (Clayton Eye Center), } \\
1000 \text { Corporate Center Drive, Suite 100, I20, I80, } \\
\text { Morrow, GA 30260, USA }\end{array}$ \\
\hline
\end{tabular}


Table S2 List and description of investigators, who enrolled at least one subject in the study, and other important participants in KPI121 1\% Trial 2

\begin{tabular}{|c|c|c|}
\hline Investigator name & Sub-investigator(s) name & Hospital/institution name and address \\
\hline Joseph R Martel, MD & James Benjamin Martel, MD, MPH & $\begin{array}{l}\text { Martel Eye Medical Group, } \\
\text { I I } 16 \text { Trinity River Drive, } \\
\text { Rancho Cordova, CA 95670, USA }\end{array}$ \\
\hline Kenneth Sall, MD & $\begin{array}{l}\text { Julie Kim, OD } \\
\text { Jade Davis, OD }\end{array}$ & $\begin{array}{l}\text { Sall Research Medical Center, } \\
\text { I I } 423 \text { I87th Street, Suite 200, } \\
\text { Artesia, CA 9070I, USA }\end{array}$ \\
\hline Michael Korenfeld, MD & Nathan Tuttle, OD & $\begin{array}{l}\text { Comprehensive Eye Care, Ltd, } \\
90 \text { I East Third Street, } \\
\text { Washington, MO 63090, USA } \\
\text { Mercy Hospital, } \\
\text { 90I East Fifth Street, } \\
\text { Washington, MO 63090, USA }\end{array}$ \\
\hline Jack Abrams, MD & Tapan R Shah, MD & $\begin{array}{l}\text { Abrams Eye Institute, } \\
6450 \text { Medical Center Street, Suite 100, } \\
\text { Las Vegas, NV 89148, USA } \\
\text { Valley View Surgery Center, } \\
\text { I330 S Valley View Boulevard, } \\
\text { Las Vegas, NV 89102, USA }\end{array}$ \\
\hline Louis M Alpern, MD & & $\begin{array}{l}\text { The Cataract and Glaucoma Center, } \\
4 I 7 I \text { N Mesa, } \\
\text { Building DI00, } \\
\text { El Paso, TX 79902, USA }\end{array}$ \\
\hline Jason Bacharach, MD & Lisa Teel, OD & $\begin{array}{l}\text { North Bay Eye Associates, } \\
\text { I04 Lynch Creek Way, Suite 12, } \\
\text { Petaluma, CA 94954, USA } \\
\text { North Bay Eye Associates, Inc, Ambulatory Surgery Center, } \\
380 \text { Tesconi Court, } \\
\text { Santa Rosa, CA 9540I, USA }\end{array}$ \\
\hline Mark T Bergmann, MD & Daniel J Hammer, MD & $\begin{array}{l}\text { Apex Eye, } \\
6507 \text { Harrison Avenue, Suite E, Cincinnati, OH 45247, USA } \\
\text { Trihealth Surgery Center, } \\
3660 \text { Edgewood Drive, } \\
\text { Cincinnati, OH 452। I, USA } \\
\text { Mercy Health West Hospital, } \\
3300 \text { Mercy Health Boulevard, } \\
\text { Cincinnati, OH 452।I, USA }\end{array}$ \\
\hline James Boyce, MD & $\begin{array}{l}\text { Norman Liu, MD } \\
\text { Ryan Taban, MD }\end{array}$ & $\begin{array}{l}\text { Orange County Ophthalmology, } \\
\text { I } 2665 \text { Garden Grove, Boulevard, Suite 40I, } \\
\text { Garden Grove, CA 92843, USA }\end{array}$ \\
\hline David L Cooke, MD & $\begin{array}{l}\text { David N Brown, MD } \\
\text { Ronald L McKey, MD } \\
\text { Stanley W Pletcher, MD } \\
\text { Duane A Tolsma, OD }\end{array}$ & $\begin{array}{l}\text { Great Lakes Eye Care, } \\
2848 \text { Niles Road, } \\
\text { Saint Joseph, MI 49085, USA } \\
\text { Great Lakes Eye Care, } \\
\text { I } 20 \text { Longmeadow Village, } \\
\text { Drive Niles, MI 49I20, USA } \\
\text { Lakeland Center for Outpatient Services, } \\
3900 \text { Hollywood Road, } \\
\text { Saint Joseph, MI 49085, USA }\end{array}$ \\
\hline
\end{tabular}


Table S2 (Continued)

\begin{tabular}{|c|c|c|}
\hline Investigator name & Sub-investigator(s) name & Hospital/institution name and address \\
\hline Michael Depenbusch, MD & $\begin{array}{l}\text { Anita Schadlu, MD } \\
\text { Ramin Schadlu, MD } \\
\text { Shabari Seetharam, MD }\end{array}$ & $\begin{array}{l}\text { Arizona Eye Center, } \\
604 \text { W Warner Road, Suite B6, } \\
\text { Chandler, AZ 85225, USA } \\
\text { Warner Park Surgery Center, } \\
604 \text { W Warner Road, } \\
\text { Building A, } \\
\text { Chandler, AZ 85225, USA } \\
\text { Scottsdale Eye Institute, } \\
2 \text { I5 S Power Road, Suite I I2, } \\
\text { Mesa, AZ 85206, USA } \\
\text { Desert Ridge Outpatient Surgery Center, } \\
20940 \text { N Tatum Boulevard, } \\
\text { \# I00, } \\
\text { Phoenix, AZ 85050, USA }\end{array}$ \\
\hline Sherif M El-Harazi, MD & Kay Park, MD & $\begin{array}{l}\text { Lugene Eye Institute, } \\
\text { I5I0 South Central Avenue, Suite 300, } \\
\text { Glendale, CA 91204, USA }\end{array}$ \\
\hline Robert H Gross, MD & $\begin{array}{l}\text { Jung T Dao, MD } \\
\text { Brandon K Suedekum, MD }\end{array}$ & $\begin{array}{l}\text { Cornea and Cataract Consultants of Arizona, } \\
3815 \text { E Bell Road, Suite } 2500 \text {, } \\
\text { Phoenix, AZ 85032, USA }\end{array}$ \\
\hline Preeya Gupta, MD & $\begin{array}{l}\text { Terry Kim, MD } \\
\text { Melissa Daluvoy, MD } \\
\text { Gargi Vora, MD } \\
\text { Robin R Vann, MD }\end{array}$ & $\begin{array}{l}\text { Duke University Eye Center, } \\
235 \text { I Erwin Road, } \\
\text { Durham, NC 27710, USA } \\
\text { Duke Eye Center, } \\
4709 \text { Creekstone Drive, } \\
\text { Durham, NC } 27703, \text { USA }\end{array}$ \\
\hline David Hardten, MD & $\begin{array}{l}\text { Ahmad Fahmy, OD } \\
\text { Christine Larson, MD } \\
\text { Elizabeth Davis, MD } \\
\text { Gina Doeden, OD } \\
\text { Johnna Hobbs, OD } \\
\text { Mona Fahmy, OD } \\
\text { Mark Bubolz, OD } \\
\text { Scott Hauswirth, OD } \\
\text { Thomas Samuelson, MD } \\
\text { Alicia Alvarado, OD }\end{array}$ & $\begin{array}{l}\text { Minnesota Eye Consultants, PA, } \\
\text { 980I Dupont Avenue S, Suite 200, } \\
\text { Bloomington, MN 5543I, USA }\end{array}$ \\
\hline Mitchell A Jackson, MD & & $\begin{array}{l}\text { Jackson Eye, SC, } \\
300 \text { N Milwaukee Avenue, } \\
\text { Lake Villa, IL 60046, USA } \\
\text { Lindenhurst Surgery Center, } \\
1050 \text { Red Oak Lane, } \\
\text { Lindenhurst, IL 60046, USA }\end{array}$ \\
\hline Brennan P Greene, MD & $\begin{array}{l}\text { John C Meyer, MD } \\
\text { Guruprasad R Pattar, MD, PhD }\end{array}$ & $\begin{array}{l}\text { The Eye Care Institute, I } 536 \text { Story Avenue, } \\
\text { Louisville, KY 40206, USA }\end{array}$ \\
\hline Karl Olsen, MD & $\begin{array}{l}\text { Kent Basford, DO } \\
\text { Randall Smith, MD }\end{array}$ & $\begin{array}{l}\text { Eye Center of Northern Colorado, PC, } \\
\text { I } 725 \text { East Prospect Road, } \\
\text { Fort Collins, CO } 80525, \text { USA }\end{array}$ \\
\hline
\end{tabular}


Table S2 (Continued)

\begin{tabular}{|c|c|c|}
\hline Investigator name & Sub-investigator(s) name & Hospital/institution name and address \\
\hline Richard J Ou, MD & John M Lim, MD & $\begin{array}{l}\text { Houston Eye Associates, } \\
915 \text { Gessner } \# 250 \text {, } \\
\text { Professional building 3, } \\
\text { Houston, TX 77024, USA } \\
\text { Houston Eye Associates, } \\
2855 \text { Gramercy Street, } \\
\text { Houston, TX 77025, USA }\end{array}$ \\
\hline James H Peace, MD & & $\begin{array}{l}\text { United Medical Research Institute, } \\
43 \text { I-433 North Prairie Avenue, } \\
\text { Inglewood, CA 9030I, USA } \\
\text { Olympia Medical Center, } \\
5900 \text { West Olympic Boulevard, Los Angeles, CA 90036, USA }\end{array}$ \\
\hline Harvey J Reiser, MD & Carrie A Cardillo, OD & $\begin{array}{l}\text { Eye Care Specialists, } \\
703 \text { Rutter Avenue, } \\
\text { Kingston, PA I8704, USA } \\
\text { Surgical Specialty Center of Northeastern Pennsylvania, } \\
190 \text { Welles Street, } \\
\text { Forty Fort, PA I8704, USA }\end{array}$ \\
\hline Philip Lee Shettle, DO & None & $\begin{array}{l}\text { Shettle Eye Research, Inc, } \\
\text { I3 I I3 66th Street N, } \\
\text { Largo, FL 33773, USA }\end{array}$ \\
\hline Bruce E Silverstein, MD & $\begin{array}{l}\text { Christopher Lin, MD } \\
\text { Robert G Trent, MD } \\
\text { Bryan G Crum, MD }\end{array}$ & $\begin{array}{l}\text { Shasta Eye Medical Group, Inc, } \\
\text { 3190 Churn Creek Road, } \\
\text { Redding, CA } 96002 \text {, USA } \\
\text { Shasta Eye Medical Group, Inc, } \\
900 \text { Butte Street, } \\
\text { Redding, CA } 9600 \text { I, USA } \\
\text { Surgery Center of Northern California, } \\
950 \text { Butte Street, } \\
\text { Redding, CA } 9600 \text { I, USA }\end{array}$ \\
\hline Steven E Smith, MD & Angela Kaplan, OD & $\begin{array}{l}\text { Eye Associates of Fort Myers, } \\
4225 \text { Evans Avenue, } \\
\text { Fort Myers, FL 3390I, USA } \\
\text { University Eye Surgery Center, } \\
\text { 1305I University Drive, } \\
\text { Fort Myers, FL 33907, USA }\end{array}$ \\
\hline Thomas Richard Walters, MD & $\begin{array}{l}\text { Robert Edward Marquis, MD } \\
\text { Yen Dang Nieman, MD }\end{array}$ & $\begin{array}{l}\text { Texan Eye, PA/Keystone Research, Ltd, } \\
57 \text { I } 7 \text { Balcones Drive, } \\
\text { Austin, TX 7873I, USA } \\
\text { Texan Eye, PA, } \\
7000 \text { North Mopac Expressway, Suite } 110 \text { and Suite } 165 \text {, } \\
\text { Austin, TX 7873I, USA } \\
\text { Texan Surgery Center, } \\
7000 \text { North Mopac Expressway, Suite I20, } \\
\text { Austin, TX 7873I, USA }\end{array}$ \\
\hline
\end{tabular}

(Continued) 
Table S2 (Continued)

\begin{tabular}{|c|c|c|}
\hline Investigator name & Sub-investigator(s) name & Hospital/institution name and address \\
\hline Jon-Marc Weston, MD, FACS & $\begin{array}{l}\text { Gregory M Valle, OD } \\
\text { Steven F Tronnes, OD }\end{array}$ & $\begin{array}{l}\text { Roseburg Research Associates, LLC, } \\
2435 \text { NW Kline Street, } \\
\text { Roseburg, OR 9747I, USA } \\
\text { Vision Surgery \& Laser Center, PC, } \\
2435 \text { NW Kline Street, } \\
\text { Roseburg, OR 9747I, USA }\end{array}$ \\
\hline Robert B Pendleton, MD & Victor Wechter, MD & $\begin{array}{l}\text { Pendleton Eye Center, } \\
3637 \text { Vista Way, } \\
\text { Oceanside, CA 92056, USA } \\
\text { North Coast Surgery Center, } \\
3903 \text { Waring Road, } \\
\text { Oceanside, CA 92056, USA }\end{array}$ \\
\hline John F Kozlovsky, MD & $\begin{array}{l}\text { Jeannine E Camacho, OD } \\
\text { Richard L Delay, OD }\end{array}$ & $\begin{array}{l}\text { Kozlovsky Delay \& Winter Eye Consultants, LLC, } \\
2929 \text { Mossrock, Suite I04, } \\
\text { San Antonio, TX 78230, USA } \\
\text { American Surgery Center, } \\
7810 \text { Louis Pasteur Drive, Suite 100, } \\
\text { San Antonio, TX 78229, USA }\end{array}$ \\
\hline Parag Majmudar, MD & $\begin{array}{l}\text { Maria Rosselson, MD } \\
\text { Tiffany Andrzejewski, OD } \\
\text { Charles Faron, OD }\end{array}$ & $\begin{array}{l}\text { Chicago Cornea Consultants, } \\
\text { I } 585 \text { N Barrington Road, Suite 502, } \\
\text { Hoffman Estates, IL 60169, USA } \\
\text { St Alexius Medical Center, } \\
\text { I555 N Barrington Road, } \\
\text { Hoffman Estates, IL 60169, USA } \\
\text { Hoffman Estates Surgery Center, } \\
\text { I555 N Barrington Road, Suite 400, } \\
\text { Hoffman Estates, IL 60169, USA }\end{array}$ \\
\hline Jeffrey Raymond Lozier, MD & Karen Mossbarger, CRC & $\begin{array}{l}\text { Arch Health Partners, } \\
\text { I56 I I Pomerado Road, } \\
\text { 4th Floor, Poway, CA 92064, USA }\end{array}$ \\
\hline Kerry D Solomon, MD & $\begin{array}{l}\text { Jeffery F Hood, OD } \\
\text { Helga P Sandoval, MD, MSCR }\end{array}$ & $\begin{array}{l}\text { Carolina Eye Care Physicians, LLC, } \\
\text { I I0I Clarity Road, Suite I00, } \\
\text { Mt Pleasant, SC 29464, USA } \\
\text { The Physicians' Eye Surgery Center, } \\
2060 \text { Charlie Hall Boulevard, Suite 30I, } \\
\text { Charleston, SC 29464, USA }\end{array}$ \\
\hline David Tyler Vroman, MD & $\begin{array}{l}\text { Millin Chandu Budev, MD } \\
\text { Michelle See Yuen Ying, MD } \\
\text { Kristina D Neff, MD }\end{array}$ & $\begin{array}{l}\text { Carolina Cataract \& Laser Center, } \\
\text { I } 37 \text { Gateway Drive, } \\
\text { Ladson, SC 29456, USA } \\
\text { Physicians Eye Surgery Center, } \\
2060 \text { Charlie Hall Boulevard, Suite 30I, } \\
\text { Charleston, SC 294I4, USA }\end{array}$ \\
\hline Don J Perez-Ortiz, MD & Bernard R Perez, MD & $\begin{array}{l}\text { International Research Center, } \\
4506 \text { Wishart Place, } \\
\text { Tampa, FL 33603, USA }\end{array}$ \\
\hline
\end{tabular}


Table S2 (Continued)

\begin{tabular}{|l|l|l|}
\hline Investigator name & Sub-investigator(s) name & Hospital/institution name and address \\
\hline Thomas LoBue, MD & Ryan Miller, OD & $\begin{array}{l}\text { LoBue Laser and Eye Medical Center, } \\
40700 \text { California Oaks Road, Suite I06, } \\
\text { Murrieta, CA 92562, USA }\end{array}$ \\
\hline Frank Wilson McDonald, MD & $\begin{array}{l}\text { Jeffery Levenson, MD } \\
\text { Curtis Schmidt, OD }\end{array}$ & $\begin{array}{l}\text { Levenson Eye Associates, } \\
75 \text { I Oak Street, Suite 200, } \\
\text { Jacksonville, FL 32204, USA }\end{array}$ \\
& $\begin{array}{l}\text { Riverside Park Surgicenter, } \\
\text { 200 I College Street, } \\
\text { Jacksonville, FL 32204, USA }\end{array}$ \\
\hline Robert C Sorenson, MD, PhD & $\begin{array}{l}\text { Barratt L Philips, MD } \\
\text { Roger Duncan Johnson, MD } \\
\text { John Grant Tew, MD }\end{array}$ & $\begin{array}{l}\text { Inland Eye Specialist, } \\
3953 \text { W Stetson Avenue, } \\
\text { Hemet, CA 92545, USA }\end{array}$ \\
\hline
\end{tabular}

\section{Publish your work in this journal}

Clinical Ophthalmology is an international, peer-reviewed journal covering all subspecialties within ophthalmology. Key topics include: Optometry; Visual science; Pharmacology and drug therapy in eye diseases; Basic Sciences; Primary and Secondary eye care; Patient Safety and Quality of Care Improvements. This journal is indexed on

\section{Dovepress}

PubMed Central and CAS, and is the official journal of The Society of Clinical Ophthalmology (SCO). The manuscript management system is completely online and includes a very quick and fair peer-review system, which is all easy to use. Visit http://www.dovepress.com/ testimonials.php to read real quotes from published authors. 